\title{
Analysis of Non-Profit Business Incubator Models: Budget Wastage or Initial Step of Progress? (Case Study of Mentoring Business Incubator for Province Government Level in Indonesia)
}

\author{
Mirsa Octavia Wardayani ${ }^{1}$, Hardi Warsono ${ }^{2}$ \\ \{mirsaow@yahoo.com\} \\ Universitas Diponegoro, Indonesia ${ }^{1,2}$
}

\begin{abstract}
The failure of business usually occurs during the first year of the business. Responding to this concern, the incubator business model is present and growing among the community. The regulation on Business Incubators in Indonesia already exists in 2015. At the same time, several central and local government have released Non-Profit Business Incubator that self-managed. The Non-Profit Business Incubator, which managed by local government usually get a double funding source, that is APBN (State Budget) and APBD (Local Budget). The number of budgets that have been managed by Non-Profit Business Incubator Local Government in each year reach around $\mathrm{Rp}$ 2.000.000.000 (two billion rupiah). This can be seen from the success rate of it reaches only $30-40 \%$ with indicator of success is about the business continuity after the incubation period. Nevertheless, rate of tenant satisfaction with the incubation services in Non-Profit Business Incubator reaches $80-90 \%$.
\end{abstract}

Keywords: Non-Profit Business Incubation, Budget Benefit, Service.

\section{Introduction}

The Model of Business Incubator was first introduced in New York. The first time, it placed in a building that was previously used to incubate chickens then changed to incubate a start-up company. Business incubators are then state-driven and expand managed businesses with the hope of becoming high business potential. Business incubators can provide resources to start businesses such as office space, counseling, and other basic services, the specific purpose is also to connect internal networks and transfer information about entrepreneurship among new corporate companies [1].

In Indonesia, the government's attention will involve the Business Incubator which has been realized through the policy of the Republic of Indonesia's Presidential Regulation Number 27 of 2013 concerning the Development of Entrepreneurial Incubators [2]. This policy was further discussed in the Republic of Indonesia Minister of Cooperatives and SMEs Regulation Number 24 of 2015 concerning Norms, Standards, Procedures and Criteria for Implementing Entrepreneurial Incubators. Entrepreneurial incubator is an intermediary institution that carries out an incubation process for incubation participants (tenants), while those who are requested by incubation are a process of guidance, assistance and development. 
The development of entrepreneurial incubators aims to create and develop new businesses that have economic value and high competitiveness, as well as optimize the use of educated human resources and move the economy through knowledge and technology. Government support through this incubator program is carried out with the aim of increasing the commercialization of innovation results that have a mature level of technological readiness. Funded innovation products are focused on products that are already at the level of technological readiness (TKT).

Referring to the seven characteristics of the entrepreneurial incubator, the entrepreneurial incubator is then expected to provide benefits that help the government obtain income through industrial income taxes, absorption of educated labor, turn on the input of raw materials, drive the wheels of distributors, transportation and markets. In addition, government investment in IBT and incubating industry participants will be doubled in revenue in five years [3].

The direction to form an incubator then has a very positive impact on the development of SMEs in Indonesia. Until 2017, it was noted that the growth of SMEs increased at a ratio of $3.1 \%$. One factor that supports this increase is the assistance that has been carried out by incubators throughout Indonesia [4].

The increase number of private incubators in Indonesia then encouraged research institutions both at central and regional levels to develop non-profit business incubators (an incubators that managed by the government). This non-profit business incubator basically has the same duties and functions as the profit business incubator in general, the difference only in the partnership. If the partnership's Business Profit Incubator is based on shared profit sharing, the Non-Profit Business Incubator is based on a SK from third parties (government grants) [5].

Non-profit business incubators are usually managed by government R\&D institutions at the central and regional levels. In Indonesia, there are two business incubators managed by the Provincial Government, namely the South Sumatra Balitbangda Business Incubator (INTENSS) and the Central Java Innovation Entrepreneurial Business Incubator (INWINOV). Both are managed by the Provincial Research Institute. The Non-Profit Business Incubator usually only relies on grant funding from the central government, which then has an impact on the sustainability of the accompanying tenants. This is not proportional to the large amount of grant funds that have been spent each year. So, it needs to be discussed again.

Nevertheless, the existence of a non-profit business incubator is felt to be able to boost the confidence of entrepreneurs, increase business networks, and increase business-related knowledge [6].

\section{Research Method}

This research is a descriptive qualitative research with data collection methods through primary and secondary data at related institutions

\section{Result and Discussion}

\subsection{Non-Profit Incubator Funding}

While carrying out their duties and functions, one of the activities in the incubator as well as Pre-Incubation activities, Incubation and Post-Incubation activities, Non-Profit 
Business Incubators are prohibited from collecting money or service fees from related tenants. This has been based on the rules that have been made by the government-related to Non-Tax State Revenues which contain "all forms of activities that supervised by non-profit state agencies or institutions are prohibited from collecting service fees".

Funding program in the Non-Profit Business Incubator is very dependent on the government budget as the incentive program provider. Based on data compiled from the Business Incubator of Central Java Province and South Sumatra Province, it appears that the tenant budget has increased significantly from year to year. The funds from the state budget that have been issued by the Ministry of Research, Technology and Higher Education in the PPBT program for the Business Incubator of Central Java Province and South Sumatra Province as shown in figure 1.

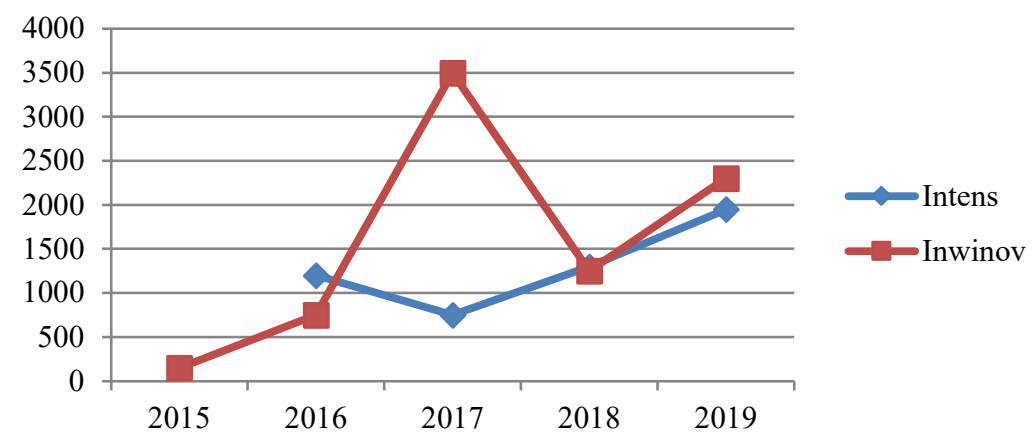

Fig. 1. Profile of South Sumatera and Central Java Business Incubator

Based on the graph, it appears that funding provided by the Ministry of Research, Technology, and Technology is fluctuating each year. This is caused by the size of the budget is very dependent on the needs of tenants and the number of tenants that are supported by the incubator.

Other data obtained from the managers of "INTENSS" and "INWINOV" found that the budget that has been used for all incubator activities does not only depend on the State Budget (APBN), but also depends on the Regional Budget (APBD). However, the activity's budgets at the BALITBANG of South Sumatra and BAPPEDA of Central Java did not specify the incubator activities in the Budget Activity Plan (RKA). The budget for incubator activities in the BALITBANG of South Sumatra is included in the R\&D (LITBANG) Services activities. Meanwhile, in BAPPEDA of Central Java, it is included in the Science and Technology Implementation (IPTEKIN) activities. Based on the 2018 Budget Expenditure Plan (RAB), the amount of the budget for Research and Development Services in the BALITBANG of South Sumatra reaches $480.000 .000,-$, meanwhile in the Science and Technology Application activities are 325.000 .000 , -

The reason for the lack of a special budget for incubators is due to the incubator of a nonprofit business run by full-time and part-time employees. Full-time employees are usually run by Non-PNS. Meanwhile, incubator part-time employees are run by PNS. The existence of these Non-PNS employees then causes the activity budget must be related to one another.

\subsection{Success Rate}

Here are the benchmarks for the successful development of a business incubator are [7]: 
a) Increases of the result from the research that has been used by the businessman.

b) Commercialization of the results from the research.

c) Increases in the number of tenants who were successfully incubated.

d) Increases in the survival rate of the tenants.

e) Increases in the number and value of cooperation networks with parties' sources of capital, markets, large industries, government bureaucracy.

f) Increases in the number and value of business incubator assets.

g) Increases in the income of the tenant.

Based on data from the accreditation forms of business incubators by Kemenristekdikti, 2018 from 2015-2019 INWINOV in Central Java has 21 tenants who have been incubated for two years, 14 of them have passed the incubation period. From the 14 tenants who have passed the incubation period, there are 6 tenants whose business has not dimmed, even reoperated after not getting funds. This then makes a record of the performance evaluation of the incubator during the incubation period.

Meanwhile, at INTENSS, from 2016 to 2019, 11 tenants had been incubated. from 11 tenants, 5 tenants had passed the incubation period. What happened at INWINOV also occurred at INTENSS, 3 out of 5 tenants who had passed the incubation period turned out to be unable to continue his business. The reason for not being able to continue his business is that the revenue has not been able to cover the overall operational costs

This data shows that more than $45 \%$ of the funding provided by the government during incubation was not successful. This means there are around 2.7 billion in funds that are not well managed by the tenants and the incubators itself.

Even so, it should be noted that there are more than $55 \%$ of tenants who have successfully developed their businesses. For example, in several tenants in Inwinov Central Java, they have successfully entered the export market and have also cooperated with large industries.

\subsection{Customer Satisfaction Rate}

Based on Kusumaningrum [6], There are several indicators that become a strength in a non-profit business incubator, namely access to fellow government agencies, extensive information networks, work targets in accordance with the direction and stability of the budget.

Based on the tenant satisfaction assessment form collected by Kemenristekdikti in 2018, INWINOV managed to get the highest evaluation value as an institutional business incubator. This is because INWINOV is able to get the seven best values in the categories of Customers Segments, Value Proportion, Channels, Customer Relationship, Key Activities, Key Partners and Cost Structure. While the shortcomings of INWINOV are in the Revenue Streams and Key Resources indicators.

Still based on the same data, INTENSS still gets less than the maximum value in each aspect of the assessment. Nevertheless, INTENSS has a good relationship with the upstream and downstream industries in South Sumatra, so that INTENSS tenants are easier to market their products.

Another data that based on Kusumaningrum [6] proven that the incubation that has been done by INWINOV has been increase profit significant. It shown by the figure 2 . 


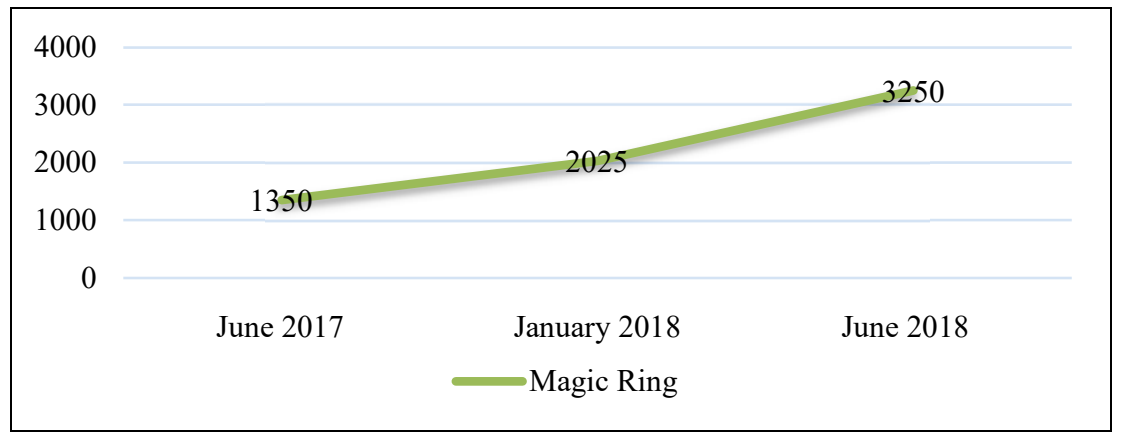

Fig. 2. Magic Ring

Source: CV. Sumi Inotech, 2018.

Based on the Figure 2, it shown that the incubation process is really works or increasing the profit of business.

\section{Conclusion}

Funding program that have been done for the incubation process is not gives effective results at $45 \%$ of tenants. this then indicates that the budget provided is wasted. however, terminating the funding program is also not a wise solution. This is because more than $55 \%$ of tenants who get funding assistance can increase their business to a better scale.

\section{References}

[1] L. G. Tobiassen, "Eating Disorders in Obsessive-Compulsive Disorder: Prevalence and Effect on Treatment Outcome." Norges teknisk-naturvitenskapelige universitet, Fakultet for ..., 2013.

[2] "Peraturan Presiden Republik Indonesia Nomor 27 tahun 2013 tentang Pengembangan Inkubator Wirausaha." .

[3] Z. T. Ichlas and S. Purwadaria, "Solvent extraction separation of nickel and cobalt from a sulfate solution containing iron (II) and magnesium using versatic 10," in AIP Conference Proceedings, 2017, vol. 1805, no. 1, p. 30003.

[4] the M. of Cooperatives, "Ratio Wirausaha Indonesia rise-to-31-persen." [Online]. Available: http://www.depkop.go.id/content/read/ratio-wirausaha-indonesia- rise-to-31-percent. [Accessed: 05-Sep-2019].

[5] "Profil INWINOV JATENG 2018.".

[6] Kusumaningrum, "Modeling and Analyzing Digital Business Ecosystems: An Approach and Evaluation," in 2018 IEEE 20th Conference on Business Informatics (CBI), 2018, vol. 2, pp. 156-163.

[7] Kemenristekdikti, Buku Panduan PPBT. 2019. 